\title{
Replacing Natural Gas by Biogas - Determining the Bacterial Contamination of Biogas by PCR
}

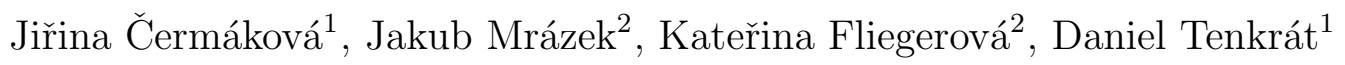 \\ ${ }^{1}$ Institute of Chemical Technology, Department of Gas, Coke and Air Protection, \\ Technická 5, 16848 Praha, Czech Republic \\ ${ }^{2}$ Institute of Animal Physiology and Genetics, AS CR, v.v.i., Vídeñská 1083, 142 20 Prague, Czech Republic \\ Correspondence to: cermakoi@vscht.cz
}

\begin{abstract}
A promising way of using biogas is to upgrade it to natural gas, which is referred to as Substitute Natural Gas (SNG) or biomethane. Biomethane, or biogas, is produced by biological processes of harnessing the ability of microorganisms to degrade organic material to methane. Some of the microorganisms are aerosolized from the digester into the biogas; afterwards a bio-film is formed that attaches to the surfaces of the distribution pipes, and can find it was to the place where the end use of biogas takes place. This paper deals with the detection of microbial species in biogas, their influence on corrosion and the potential risk that diseases can be spread via biogas using molecular techniques. Using molecular methods, we found that raw biogas contains about 8 million microorganisms per $\mathrm{m}^{3}$, which is most likely the result of microbial transmission from the anaerobic digestion process. Some bacterial species may contribute to the corrosion of pipelines and equipment; others are opportunistic pathogens that can cause toxic reactions. However, most bacterial species, more than $40 \%$ in biogas, are still unknown, as is their influence on the digestion process and on human health. Further studies are needed to better understand the behavior of microorganisms in anaerobic digestion and to prevent microbial-influenced corrosion and microbial dissemination.
\end{abstract}

Keywords: biomethane, PCR, microorganisms.

\section{Introduction}

Biogas is produced by anaerobic digestion of organic substrates, such as manure, sewage sludge, energy crops and the organic fractions of household and industrial wastes. These raw materials are not technologically and economically suitable for combustion. The substrate composition affects the yield and the composition of the biogas. Biogas consists mainly of methane (50-65\%) and carbon dioxide (35-50\%), but it also contains a number of other minor elements, e.g. solid particles, nitrogen, water vapour, oxygen, hydrogen sulphide and ammonia [1].

The most common use of biogas is as a fuel for co-generation units, which generate Combined Heat and Power (CHP), because the production of electricity is supported by many mechanisms in the Czech Republic. The electricity that is produced is consumed by the plant itself (typically 5 to $10 \%$ of the total electricity that is produced). However, most of the electricity is sold to the local electrical grid. As far as heat is concerned, the situation is quite different. More than $60 \%$ of the heat that is produced is difficult to utilize effectively over the whole year, especially during summer. The heat is needed for operating the plant (usually between 10-15\%). It can also be used for other purposes, e.g. for heating service buildings. Low utilization of the heat is due to the location of the biogas plant, usually far from a city or from industrial buildings. Excessive heat often worsens the overall energy balance of biogas use and, as a result, the overall efficiency is in reality less than $65 \%$ of the input energy, and indeed, often even well below $35 \%$.

A more effective way of using biogas is to upgrade it to natural gas, which is referred to a Substitute Natural Gas (SNG) or biomethane. Biomethane has similar properties and uses to those of natural gas, and can be injected directly into the local natural gas distribution grid. Biogas can be transferred to a different place from the place where it was produced, and thus all the heat that is produced can be utilized. To do this, carbon dioxide and all remaining trace elements (hydrogen sulphide, water vapour, etc.) must first be removed. This increases the concentration of methane, resulting in improved energy density. Various commercial technologies are used for removing undesirable components from biogas; the most common are pressure swing adsorption (PSA), water scrubbing and chemical absorption. Other technolo- 
gies are at the pilot or demonstration plant level, e.g. membrane separation or cryogenic separation $[2,3]$. The best technology is selected on the basis of the composition of the raw biogas, the size of the plant, and the investment cost. The energy required for upgrading process depends on the technology that is used, but generally the requirement is $5-10 \%$ of the energy content of the biogas that is produced. This means that more than $70 \%$ of the energy is available for other uses.

If biomethane is injected into the local natural gas distribution grid and is transported to its destination with higher efficiency, it has to be compressed to the pressure of the local distribution grid, and an odor has to be added so that any leaks are detected. In order to ensure the safety, integrity and operability of gas networks, biomethane has to meet certain minimum gas quality requirements. The choice of gas quality parameters and their limiting values are generally specified nationally. In the Czech Republic, TPG 90202 refers to the quality of the biomethane supplied in networks [4]. Unfortunately, there are technological and administration barriers and obstacles in the promotion of biogas as biomethane. For example, there are no specific requirements for frequency and monitoring of the gas quality, and there are no regulations on organizational and investment problems, etc.

Biomethane can also be used as a fuel for vehicles that run on natural gas. These vehicles have several advantages over vehicles equipped with petrol or diesel engines, especially ecological advantages. The emissions of $\mathrm{NOx}$ and dust particles are drastically reduced, and the emission of $\mathrm{CO}_{2}$ decreases by more than $35 \%$. In the Czech Republic, the major obstacle to wider use of CNG is the limited number of CNG filling stations.

\section{Microorganisms in biogas}

Biomethane, or biogas, is produced by biological processes of harnessing the ability of microorganisms to degrade organic material to methane. Some of the microorganisms are aerosolized from the digester into the biogas; afterwards form a biofilm that is fixed to the surfaces of distribution pipes. This biofilm can be dislodged and so get to the place of end usages biogas. Most of the biogas that is produced comes from treated sewage sludge and biogas plants, and these systems do not contain a pasteurization step. Pathogens can therefore be found in biogas. Introducing the biogas that is produced into systems constructed for natural gas is currently a matter for debate about the risks of introducing pathogens into gas systems.

The microbial communities in the biogas are not just a rough copy of anaerobic digester microbial communities, and not all microorganisms are equally conveyed by biogas. Given this dispersal process, three types of behaviors appear to be possible: the first type is passive behavior. It means that the microorganisms are randomly floated out by the biogas. The other two types of behavior are active: they either seek to avoid transport into a hostile environment, or to use transport for dissemination [6].

Investigations of microbial species present in biogas or in natural gas have traditionally relied on the use of laboratory culture methods. Laboratory growth media cannot accurately reflect the true condition within a pipeline. In addition, it is known that at present only a small part (generally less than $1 \%$ ) of the total microbial diversity can be cultivated. The remaining part is composed of microorganisms for which no culture methods have yet been found, or which are in a viable but non-cultivable state. Molecular techniques enable a better appreciation of the compositions and the variability of microbial communities than traditional bacterial cultures [7].

\section{Material and methods}

Two different biogases were investigated: biogas from a biogas plant processed energy crop, grass silage and manure, and biogas from a waste water treatment plant (WWTP) equipped with an adsorption unit that is designed for sulphur and siloxane removal. Biogas samples for DNA extraction were collected by filtration through a $0.22 \mu \mathrm{m}$ nylon membrane filter (Millipore) directly behind the digester and the adsorption unit. Anaerobic digester substrate and sludge were also analyzed. Natural gas from the distribution grid was also collected in order to draw a comparison between microbial diversity of natural gas and biogas. All samples were frozen for transport with dry ice, and DNA extractions were performed according to the methods described by Bartosh et al. (2004). [8] The total DNA was purified using a PowerSoil DNA Isolation Kit (MoBio) according to the manufacturer's protocol. Two analyses were made: real time PCR (qPCR) and PCR + DGGE (Polymerase Chain Reaction + Denaturing Gradient Gel Electrophoresis). qPCR was used for quantifying bacterial DNA. The target organisms were quantified using specific primers of chosen bacterial groups, and the qPCR results that were obtained were expressed as numbers of bacteria cells per gram of substrate or sludge or per cubic meter of gas. The second analysis determined the bacterial species [8-12]. PCR was realized by targeting $16 \mathrm{~S}$ rRNA gene sequences with universal bacterial primers 338GC (5' - CGC CCG CCG CGC CCC GCG CCC GGC CCG CCGCCGCCGCCG CAC TCC TAC GGG AGG CAG CAG 3') and RP534 (5' - ATT ACC GCG GCT GCT GG - 3') [13]. The PCR products were processed 
Table 1: Identification of bacterial from DGGE $[15,16]$

\begin{tabular}{|c|c|c|c|c|}
\hline Location & Organisms & $\begin{array}{l}\mathrm{S}^{\mathrm{A}} \\
{[\%]}\end{array}$ & Classification & $\begin{array}{l}\text { Main characteristics } \\
\text { and indication of } \\
\text { pathogenicity }\end{array}$ \\
\hline $\mathrm{B} 1 \mathrm{~W}, \mathrm{~B} 2 \mathrm{~W}, \mathrm{NG}$ & Pseudomonas sp. & 95 & $\begin{array}{l}\text { Proteobacteria; } \\
\text { Gammaproteobacteria }\end{array}$ & $\begin{array}{l}\text { Reduce nitrate to } \\
\text { nitrite, opportunistic } \\
\text { pathogen }\end{array}$ \\
\hline \multirow{2}{*}{$\begin{array}{l}\text { B1W, B2W, BB, } \\
\text { NG }\end{array}$} & Butyvibrio sp. & \multirow[t]{2}{*}{99} & \multirow[t]{2}{*}{ Firmicutes; Clostridia } & \multirow{2}{*}{$\begin{array}{l}\text { Decompose cellulose } \\
\text { and amylum, can } \\
\text { cause microbial } \\
\text { corrosion }\end{array}$} \\
\hline & Pseudobutyvibrioruminis & & & \\
\hline SW & $\begin{array}{l}\text { Uncultured beta } \\
\text { proteobacterium }\end{array}$ & 99 & $\begin{array}{l}\text { Proteobacteria; } \\
\text { Betaproteobacteria }\end{array}$ & $\begin{array}{l}\text { Typical for waste } \\
\text { water treatment plants }\end{array}$ \\
\hline $\mathrm{B} 1 \mathrm{~W}, \mathrm{~B} 2 \mathrm{~W}, \mathrm{SW}$ & Sphingomonas sp. & 99 & $\begin{array}{l}\text { Proteobacteria; } \\
\text { Alphaproteobacteria }\end{array}$ & $\begin{array}{l}\text { Decompose } \\
\text { polysaccharide, can } \\
\text { cause infection }\end{array}$ \\
\hline SB & Lactobacillus fermentum & 98 & $\begin{array}{l}\text { Firmicutes; } \\
\text { Lactobacillales }\end{array}$ & $\begin{array}{l}\text { Produce lactic acid, } \\
\text { can cause infection }\end{array}$ \\
\hline SB & $\begin{array}{l}\text { Uncultured Lachnospiraceae } \\
\text { bacterium }\end{array}$ & 98 & $\begin{array}{l}\text { Firmicutes; } \\
\text { Clostridia }\end{array}$ & - \\
\hline SB, SW & $\begin{array}{l}\text { Uncultured Bacteroidetes } \\
\text { clone }\end{array}$ & 100 & Bacteroidetes & $\begin{array}{l}\text { Produce propionic, } \\
\text { lactic and acetic acid, } \\
\text { can cause infection }\end{array}$ \\
\hline $\mathrm{B} 1 \mathrm{~W}, \mathrm{NG}$ & Uncultured clostridium clone & 36 & Firmicutes, Clostridia & - \\
\hline $\mathrm{B} 2 \mathrm{~W}$ & Leucobacter & 100 & $\begin{array}{l}\text { Actinobacteria; } \\
\text { Actinobacteridae }\end{array}$ & - \\
\hline SB & $\begin{array}{l}\text { Uncultured Bacteroidetes } \\
\text { bacterium }\end{array}$ & 95 & Bacteroidetes & $\begin{array}{l}\text { Produce propionic, } \\
\text { lactic and acetic acid, } \\
\text { can cause infection }\end{array}$ \\
\hline NG & $\begin{array}{l}\text { Uncultured clostridiales } \\
\text { bacterium }\end{array}$ & 100 & Firmicutes, Clostridia & - \\
\hline $\begin{array}{l}\mathrm{B} 1 \mathrm{~W}, \mathrm{~B} 2 \mathrm{~W}, \mathrm{BB}, \\
\mathrm{SW}, \mathrm{SB}, \mathrm{NG}\end{array}$ & E. coli & 100 & $\begin{array}{l}\text { Proteobacteria; } \\
\text { Gammaproteobacteria }\end{array}$ & $\begin{array}{l}\text { From intestinal } \\
\text { micro-flora, can cause } \\
\text { toxins }\end{array}$ \\
\hline NG & Staphylococcus sp. & 100 & Firmicutes; Bacili & $\begin{array}{l}\text { Very adaptable } \\
\text { pathogen }\end{array}$ \\
\hline $\mathrm{B} 1 \mathrm{~W}, \mathrm{~B} 2 \mathrm{~W}, \mathrm{NG}$ & Pseudomonas fluorescens & 99 & $\begin{array}{l}\text { Proteobacteria; } \\
\text { Gammaproteobacteria }\end{array}$ & $\begin{array}{l}\text { Reduce nitrate, } \\
\text { opportunistic } \\
\text { pathogen }\end{array}$ \\
\hline SW & $\begin{array}{l}\text { Candidatus } \\
\text { Nitrospiradefluvii }\end{array}$ & 99 & Nitrospirae; Nitrospira & Reduce nitrate \\
\hline
\end{tabular}

$\mathrm{S}^{A}$ Column $\mathrm{S}$ for percentage similarity of closest sequence in GenBank

$\mathrm{B} 1 \mathrm{~W}$ biogas behind the digester from waste water treatment

B2W biogas behind the adsorption unit from waste water treatment

BB biogas from biogas plant

SW sludge from waste water treatment

SB substrate from biogas plant

NG natural gas 
Table 2: Number and type of microorganisms found in the digester and biogas

\begin{tabular}{|c|c|c|c|c|c|}
\hline \multirow{2}{*}{$\begin{array}{l}\text { Microorganisms/ } \\
\text { sample }\end{array}$} & \multicolumn{2}{|l|}{ Substrate } & \multicolumn{3}{|l|}{ Biogas } \\
\hline & 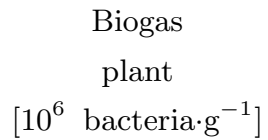 & 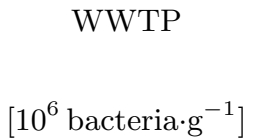 & $\begin{array}{c}\text { Biogas } \\
\text { plant } \\
{\left[10^{6} \text { bacteria } \cdot \mathrm{m}^{-3}\right]}\end{array}$ & $\begin{array}{l}\text { WWTP behind } \\
\text { digester } \\
{\left[10^{6} \text { bacteria } \cdot \mathrm{m}^{-3}\right]}\end{array}$ & $\begin{array}{l}\text { WWTP behind } \\
\text { adsorption unit } \\
{\left[10^{6} \text { bacteria } \cdot \mathrm{m}^{-3}\right]}\end{array}$ \\
\hline Total number & 80.7 & 1360 & 11.2 & 70.5 & 34.3 \\
\hline C. leptum & 6.38 & 940 & 0.46 & 5.09 & 0.62 \\
\hline Desulfovibrio & 25.8 & 124 & 0.64 & 3.46 & ND \\
\hline Faecallibacter & 3.11 & 7.16 & ND & ND & 0.5 \\
\hline Lactobacillus & 17.9 & 49.9 & ND & $\mathrm{ND}$ & ND \\
\hline Enterobacteriaceae & 0.003 & 0.04 & 0.025 & 0.047 & 0.04 \\
\hline Other & 27.5 & 244 & 10 & 64.9 & 33.7 \\
\hline
\end{tabular}

Table 3: Number and type of microorganisms found in the natural gas

\begin{tabular}{|c|c|c|c|c|c|}
\hline \multirow{2}{*}{$\begin{array}{l}\text { Microorganisms/ } \\
\text { sample }\end{array}$} & \multicolumn{5}{|l|}{ Natural gas } \\
\hline & 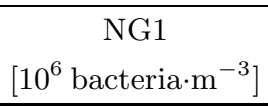 & $\begin{array}{c}\text { NG2 } \\
{\left[10^{6} \text { bacteria } \cdot \mathrm{m}^{-3}\right]}\end{array}$ & $\begin{array}{c}\text { NG3 } \\
{\left[10^{6} \text { bacteria } \cdot \mathrm{m}^{-3}\right]}\end{array}$ & $\begin{array}{c}\text { NG4 } \\
{\left[10^{6} \text { bacteria } \cdot \mathrm{m}^{-3}\right]}\end{array}$ & $\begin{array}{c}\text { NG6 } \\
{\left[10^{6} \text { bacteria } \cdot \mathrm{m}^{-3}\right]}\end{array}$ \\
\hline Total number & 3.08 & 2.11 & 8.37 & 18.8 & 4.29 \\
\hline C. leptum & 0.50 & 0.41 & 2.6 & 5.06 & 1.55 \\
\hline Desulfovibrio & 0.20 & 0.05 & 0.31 & - & 0.24 \\
\hline Faecallibacter & - & - & - & - & - \\
\hline Lactobacillus & - & - & - & - & - \\
\hline Enterobacteriaceae & 0.009 & - & 0.014 & - & 0.007 \\
\hline Other & 2.36 & 1.65 & 5.45 & 13.7 & 2.49 \\
\hline
\end{tabular}

by DGGE on the DCodeTM Universal Mutation Detection System (Biorad, USA). Finally, we compared the obtained sequences with the GenBank database, using the BLASTn algorithm. [14]

\section{Results and discussion}

The microbial diversity of all samples was assessed and compared by PCR-DGGE fingerprinting analysis of bacterial $16 \mathrm{~S}$ rRNA. The presence of bacteria in particular samples and their main characterization are shown in Table 1. Similarities based on sequence comparison varied between 36-100\%, whereby $94 \%$ of the total sequence presented more than $95 \%$ similarity with the known sequences found in the GenBank database. Only one sequence showed $36 \%$ similarity. Butyvibrio sp., Pseudobutyvibrioruminis and $E$. coli were present in all gaseous samples, while the others were present only in sludge or substrate.

The results obtained from real time PCR are shown in Table 2 and Table 3. The comparison of biogas and digester microbial diversity shows that Clostridium leptum, Desulfovibrio group, Feacallibac- terium group, Enterobacteriaceae family and Lactobacillus group appeared to be present in significantly greater numbers in the anaerobic digester than in the biogas (Table 2). This is in accordance with the idea that only some microorganisms from the digester were taken up in the biogas. The data revealed that the total number of microorganisms in the biogas behind the digester were two times higher than the total number behind the adsorption unit. This decrease could be explained by the capture of microorganisms on activated carbon.

We detected only four bacterial genera in biogas (Table 2), but more than $40 \%$ of the detected microorganisms are unknown bacterial species. Desulfovibrio and Clostridium were the most frequently detected genera that produce acidic conditions and hence accelerate the corrosion process. Enterobacteriaceae was the least present genus. It decomposes sugars to lactic acid and reduces nitrate to nitrite. This family also includes many pathogens, such as Salmonella and E. coli.

Upgraded biogas can be injected into the natural gas distribution grid. For safety reasons against microbial contamination, the microbial diversity of 
natural gas was therefore also analyzed. We detected $3-19 \cdot 10^{6}$ bacteria $\cdot \mathrm{m}^{-3}$, depending on the pressure in the distribution grid and the material of the pipeline (Table 3). This value is quite similar to that found in biogas. We found three bacterial genera in natural gas: C. leptum, Desulfovibrio and Entrerobacteriaceae. Lacobacillus and Feacalibacter were not present, because they come from intestinal microflora and participate in a fermentation process.

\section{Conclusion}

Biogas as a renewable energy source has been receiving growing attention in the Czech Republic and in the EU countries. Nowadays, there are two main ways of using biogas: as a fuel for a co-generation unit or by upgrading it to natural gas. When it is upgraded to natural gas, there is a potential risk of spreading disease via biogas. Using molecular methods, we found that raw biogas contains microorganisms, most likely as a result of microbial transmission from the anaerobic digestion process. However, natural gas contains a quite similar quantity of microorganisms as biogas. Our results show that Firmicutes and Proteobacteria were the most frequently encountered bacterial phyla. Some bacterial species may contribute to corrosion of pipelines and equipment; others are opportunistic pathogens that can cause toxic reactions. However, most of bacterial species, more than $40 \%$ in biogas, are still unknown, as is their influence on the digestion process and on human health. Further studies are needed for a better understanding of the behavior of microorganisms in anaerobic digestion, and to prevent microbial-influenced corrosion and microbial dissemination.

\section{Acknowledgement}

This work received financial support from Specific University Research (MSMT No. 21/2011), the National Agency for Agriculture Research (project No. QI92A286/2008), and the Czech Science Foundation (project No. P503/10/P394).

\section{References}

[1] Straka, F., a kol.: Bioplyn. 2. roz. vyd. Praha : Gas, s.r. o., 2006.

[2] Weidner, E.: Technologien und Kosten der Biogasaufbereitung und Einspeisung in das Erdgasnetz. Ergebnisse der Markterhebung 2007-2008. Institut Umwelt-, Sicherheits-, Energietechnik, 2008.

[3] Tentscher, W.: Anforderung und Aufbereitung von Biomas zur Einspeisung Erdgasnetze. Gas Erdgas, 2007.
[4] TPG 902 02. Jakost a zkoušeni plynných paliv s vysokým obsahem methanu. GAS, s.r.o., 2009.

[5] Deublein, D., Steinhauser, A.: Biogas from Waste and Renewable Sources. An Introduction. Weinheim : 2008. ISBN 978-3-527-31841-4.

[6] Molleta, M., Delgenes, J. P., Godon, J. J.: Differences in the aerosolization behaviour of microorganisms as revealed through their transport by biogas, Science of the Total Environment, 2007, p. 75-88.

[7] Malik, S., Beer, M., Megharaj, M., Naidu, R.: The use of molecular techniques to characterize the microbial communities in contaminated soil and water. Env. International, 2007, Vol. 34, p. $265-276$.

[8] Bartosch, S., Fite, A., Macfarlane, G. T., Mcmurdo, M. E. T.: Characterization of Bacterial Communities in Feces from Healthy Elderly Volunteers and Hospitalized Elderly Patients by Using Real-time PCR and Effects of Antibiotic Treatment on the Fecal Microbiota, Appl. Environ. Microbiol. 2004, Vol. 70, 6, p. 3575-3581.

[9] Nadkarmi, M. A., Martin, E. F., Jacques, N. A., Hunter, N.: Determination of Bacterial Load by Real-time PCR Using a Broad-range (Universal) Probe and Primers Set. Microbiol. 2002, Vol. 148, 1, p. 257-266.

[10] Shen, J., Zhang, B., Wei, G., Pang, X., Wei, H., Li, M., Zhang, Y., Jia, W., Zhao, L.: Molecular Profiling of the Clostridium Leptum Subgroup in Human Fecal Microflora by PCRDenaturing Gradient Gel Electrophoresis and Clone Library Analysis, Appl. Environ. Microbiol. 2006, p. 5 232-5 238 .

[11] Salzman, N. H., Hung, K., Haribhai, D., Chu, H., Karlsson-Sjberg, J., Amir, E., Teggatz, P., Barman, M., Hayward, M., Eastwood, D., Stoel, M., Zhou, Y., Sodergen, E., Weinstock, G. M., Bewins, C. L., Williams, C. B., Bos, N. A.: Enteric Defences Are Essential Regulators of Intestinal Microbial Ecology, Nat. Immunol. 2009, Vol. 11, p. 76-82.

[12] Rinttila, T., Kassinen, A., Malinen, E., Krogius, L., Palva, A.: Development of an extensive set of $16 \mathrm{~S}$ rDNA-targeted primers for quantification of pathogenic and indigenous bacteria in faecal samples by real-time PCR, J. Appl. Microbiol. 2004, Vol. 97, p. 1166-1177.

[13] Muyzer, G., De Waal, E., Uitterlinden, A. G.: Profiling of complex microbial populations by denaturing gradient gel electrophoresis analysis of polymerase chain reaction amplified genes 
coding for 16S rRNA. Applied and Environmental Microbiology, 1993, p. 695-700.

[14] Maidak, B. L., Larsen, N., Mccaughey, M. J., Overbeek, R., Olsen, G. J., Foge, K., Blandy, J., Woese, C. R.: The ribosomal database project. Nucleic Acid. Res. 1994, Vol. 22, p. 3485-3 487.
[15] http://microbewiki.kenyon.edu/index.php/ Bovine_Rumen, downloaded on 14. 11. 2010.

[16] Atlas, R. M.: Principles of microbiology. Dubuque : McGraw-Hill, 1997. ISBN 0-8151-0889-3. 